\title{
Firm Valuation, Market Responses, And Accounting Conservatism
}

Karin A. Petruska, Ph.D., Youngstown State University, USA

Gulraze Wakil, Ph.D., Carleton University, Canada

\begin{abstract}
This study examines whether the components of accounting conservatism as described in Watts (2003a): contracting, litigation, regulation, and taxation, provide insight on the value relevance of financial information. During the years 1993 through 2009, we explore whether these four factors are value relevant in capturing information in contemporaneous stock returns and prices and whether the trends in value relevance for these drivers vary across time. Specifically, our study aids in helping to reconcile the competing results of Balachandran and Mohanram (2011), who state that there is no compelling evidence that firms with higher levels of accounting conservatism exhibit decreasing levels of value relevance, and Lev and Zarowin (1999), who suggest that accounting conservatism is a factor causing a decline in the usefulness of financial information over time. Our results provide evidence that the level of contracting, litigation, and regulation are associated with returns and prices and their value relevance has not decreased over time, findings which differ from Lev and Zarowin (1999), and support Balachandran and Mohanram (2011), such that the expectation of these drivers are associated with value relevance. In addition, we find less consistent evidence that the taxation explanation of accounting conservatism is associated with value relevance.
\end{abstract}

Keywords: Value Relevance; Conservatism; Contracting; Litigation; Regulation; Taxation

\section{INTRODUCTION}

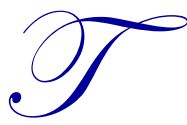

his study examines the explanations (interchangeably referred to as drivers) of accounting conservatism in order to compare value relevance by explaining their pooled, cross-sectional associations with contemporaneous stock returns and prices. Since the seminal work of Ball and Brown (1968) and Beaver (1998), subsequent association studies modeling the relationship between stock returns and earnings measures have evolved into the stream of research known as value relevance. According to Beaver (2002), value relevance research explores the statistical association between a security or market value-based dependent variable and a set of independent accounting variables. Value relevance research is concerned with identifying the drivers of firm value derived from fundamental financial statement items and whether the market impounds this information content to explain the variation in prices and returns. Value relevance research is also concerned with how the marketplace reflects the trend in information over time. Our primary metric to assess value relevance is the magnitude and statistical significance of the coefficients on the respective explanations of conservatism.

It has been documented in the extant literature that the value relevance of accounting information has been decreasing over time. Prior research suggests that the value relevance between stock market returns and earnings (Francis and Shipper, 1999) has been decreasing over the last 40 years and there has occurred a shift in the explanatory power from earnings to book values (Collins et. al, 1997), even though earnings are considered a summary measure of firm performance (Ou and Penman, 1989, Dechow, 1994). Reasons for this decline are based on the view that earnings are noisy and may not reflect real economic changes. Another reason offered for the decline suggests that there is unknown "other information" that is not incorporated in the financial statements due to measurement conflicts, lack of disclosure, or the inability to form proper estimates, which is often the case with intangible assets and research and development. For example, Lev and Zarowin (1999) find that firm innovation 
measures such as R\&D and capital intensity may be responsible for the deterioration in the informativeness of financial information and for the decline in value relevance over time.

Accounting conservatism is often viewed as one of the "other" corporate disclosure mechanisms governing financial reporting (Guay and Verrecchia, 2007). Conservatism is an accounting principle that has been used for centuries. It discourages firms from reporting aggressive earnings and book values. Accounting conservatism has been noted to influence financial practices and has been increasing over several decades (Basu, 1997; Givoly and Hayn 2000). In fact, Klein and Marquardt (2006) show that the increasing percentage of loss firms in U.S. financial markets can actually be attributed to the use of accounting conservatism.

Watts (2003a, 2003b) offer four explanations for the use of conservative accounting practices: contracting, litigation, regulation, and taxation. In effect, the objective of conservative reporting is to improve contract efficiency, to deter shareholder litigation against both firms and auditors, to increase the quality of financial information by both private and governmental regulatory intervention, and to decrease or defer income tax liability. Qiang (2007) further examines each of these factors and maintains that contracting generates conditional conservatism, litigation prompts unconditional and conditional conservatism, and regulation and taxation induces unconditional conservatism. Taken together, these findings suggest that there are distinct motivational roles for the explanations offered for accounting conservatism.

Intuitively then, it is expected that variables such as accounting conservatism are presumed to significantly capture the value relevance of accounting earnings and to improve the usefulness of information that benefits investors, sell-side analysts, and regulatory agencies. Yet, Lev and Zarowin (1999) and Ryan and Zarowin (2003) suggest that accounting conservatism may be one such factor that is actually causing a decline in the usefulness of accounting information due to the asymmetric and discretionary nature of recognizing gains and losses and the subsequent difficulty in the markets' and investors' abilities to gauge and assimilate this information. For example, conservatism involves a discretionary choice by management which can alter the reported earnings stream through adjustments which are not timely compounded in prices and returns.

However, Holthausen and Watts (2001) contend that the association and the related objective of standard setting must be stated a priori in order for value relevance studies to have implications for standard setters. For example, the consideration of contracting is one such factor which they state can influence standard setting, but is not incorporated into value relevance studies. As such, contracting can be considered a standard-setting criterion. We believe our study is a step in that direction because we decompose accounting conservatism into its respective explanations, one of which includes contracting.

Although a large stream of research has developed in the area of accounting conservatism, whether accounting conservatism produces value relevant information in the financial statements and whether this information is valued by the market over time has received limited attention. Most recently, Balachandran and Mohanram (2011) empirically investigate whether the decline in value relevance can be attributed to the increasing use of conservatism as advocated by Lev and Zarowin (1999) and Ryan and Zarowin (2003). However, Balachandran and Mohanram's (2011) results signify that there is no compelling evidence that firms with higher levels of accounting conservatism exhibit decreasing levels of value relevance. In fact, they note that firms that have exhibited no increasing levels of accounting conservatism have actually experienced a decline in value relevance in equity markets based on two summary measures of conservatism. These measures consist of the downward bias in book values using the Ohlson $(1995,2001)$ and Feltham and Ohlson (1995) framework.

Moreover, using cross-country analysis, Brown et al. (2006) find that conditional conservatism is positively related to the value relevance of earnings, but is conditioned on country-level accrual intensity. That is, their findings indicate that when accrual intensity is higher, firms that use more earnings conservatism exhibit more value relevant earnings. On one hand, Kwon et al. (2006) find that conservative accounting increases for firms in the high technology sectors, while, on the other hand, Francis and Shipper (1999) find no evidence of a decline in value relevance of financial statements for high tech industries over a forty-year time period. Using extensions to the Basu (1997) model, Jenkins et al. (2009) provide evidence that the value relevance of accounting conservatism is dependent on the business cycle, specifically with regards to U.S economic contractions versus expansions. 
Overall, these mixed results suggest the need to study the relationship between value relevance and conservative accounting further. As such, we link together the studies of Balachandran and Monhanram (2011), Watts (2003a, 2003b), and Qiang (2007) by examining the ability of contemporaneous stock returns and prices to capture information in terms of a more defined level of accounting conservatism based on the four explanations of: contracting, litigation, regulation, and taxation. We are motivated by Qiang (2007) who also states that unconditional conservatism reduces conditional conservatism, suggesting that the explanations for accounting conservatism represent interrelated, as well as distinct roles, alluding that there are tradeoffs among them (Qiang 2007). For example, Watts (2003a, 2003b) notes that prior to 1996, litigation instances were rare, especially in regards to class action lawsuits; whereas, contracting has been described as existing for ages (Holthausen and Watts, 2001). The evidence on regulation and taxation has been stated as providing a weaker explanation for accounting conservatism than contracting and litigation (Watts 2003b).

The objective of our research is to provide evidence on whether the stock market recognizes these explanations as value relevant, i.e., whether the drivers of accounting conservatism are significantly associated with returns and prices. Next, we evaluate whether value relevance changes over time based on time trend analyses.

We provide evidence that the level of contracting, litigation, and regulation are significantly associated with returns and prices, findings which differ from Lev and Zarowin (1999) and support the expectation that these drivers are associated with value relevance. We find less consistent evidence that taxation is associated with value relevance. Our results are also robust to additional sensitivity tests including the Fama-Macbeth (1973) method. Over time, we find no evidence that there is a decline in the trend of value relevance. In fact, the value relevance for the explanations of contracting and regulation actually increase over time.

The remainder of this paper is organized as follows. Section II reviews the relevant literature and the research development. Section III presents the research design and models selected. Data sources and the sample selection process are discussed in Section IV and Section V discusses the empirical results. Section VI includes additional robustness checks and Section VII provides a summary and conclusion along with suggestions for future research.

\section{LITERATURE REVIEW AND RESEARCH DEVELOPMENT}

The purpose of financial reporting is to provide not only reliable information about firm profitability, but also to report timely and value relevant information that users of financial statements can use in their capital market assessments. Conservatism is an accounting principle that tries to achieve these purposes and has been defined early on by Bliss (1924, p. 110). His definition includes "anticipate no profits, but anticipate all losses." Moreover, conservatism is often differentiated between unconditional and conditional conservatism. Unconditional conservatism arises due to accounting principles and processes (e.g., immediately expensing R\&D, changes in inventory valuation methods, and accelerated depreciation) which often occur prior to the application of conditional changes (conditional conservatism) such as the impairment of losses or assets due to the discretion of management. Beaver and Ryan (2005) analytically show that unconditional conservatism "pre-empts" conditional conservatism.

A major reason for determining value relevance relates to the FASB's Conceptual Framework. One of their statements in the framework maintains that a purpose of financial reporting is to provide information that will be useful for business decision making (Statement of Financial Accounting Concepts No. 1, FASB 1978). Decision usefulness is also defined in terms of qualitative characteristics consisting of relevance, reliability, comparability, and consistency that are reflected in equity values (Schipper and Vincent, 2003).

Previous research (Watts 2003a, 2003b; Leone and Zimmerman, 2006; Qiang, 2007) affords explanations for accounting conservatism from the demand perspective of users of financial statements. Watts (2003a, 2003b) classifies these explanations/drivers of conservatism as contracting, litigation, regulation, and taxation. Qiang (2007) further decomposes each of these conservatism explanations into whether they are due to unconditional or conditional conservatism and provides proxies that can be used for each of the explanations. 
Accounting for the four drivers of conservatism and determining their value relevance is important for many reasons. In general, findings in favor of no increase in value relevance of earnings are supported by Ball et al. (2008) who state that equity markets are not the only participants who demand financial information, thus underscoring association studies that attempt to find significant relations or changes in $\mathrm{R}^{2}$ over time. Using accounting conservatism as a proxy that represents an important feature of financial reporting, they find that debt markets, as opposed to equity markets, are positive and significantly associated with conservatism. If more information is being demanded by debt markets, this could explain why there is no supportive evidence of any directional value relevance of accounting conservatism over time in equity markets. For this reason, our study also considers contracting costs that relate to the inclusion of both debt and equity markets for contracting purposes.

Below we provide a brief description of each of the explanations of accounting conservatism.

\section{Contracting}

Contracting reduces the agency problem of asymmetric information to external constituents such as shareholders and lenders to the firm by constraining managements' opportunistic behavior to increase financial benchmarks that are used in debt covenant contracts and mitigates the tendency to upwardly bias financial information for the benefit of a firm's own economic welfare. Beatty et al. (2008) find that two thirds of their sample includes income escalators (constraints on net worth covenants that exclude a portion of net income from debt covenant calculations) within the financial reporting of the firm. The use of financial information for contracting purposes is also beneficial for compensation functions because it constrains management opportunities for compensation payments, employment contracts, and payments to other parties to the firm, leading to better firm accountability.

\section{Litigation}

Managers, auditors, and directors are more likely to be sued if earnings are overstated than if they are understated (Watts, 1993, 2003a, 2003b). This asymmetry of litigation costs leads firms to choose conservative accounting to reduce earnings if they are faced with high litigation costs. Auditors are among one of the major groups that are subject to litigation risk due to the deep pockets hypothesis (Lennox, 1999). The risk borne by auditors can be passed on to firms because auditors are less willing to accept aggressive accounting (Kinney and Uecker, 1982; Qiang, 2007). In fact, Qiang (2007) uses Big-N audit firms as a proxy for conservatism due to increases in litigation risk. Contemporaneous research has also suggested that U.S. accounting practices are increasingly more conservative than other countries due to higher levels of litigation risk. According to Watts (2003a, 2003b), firms with unexpected increases in litigation are more prone to use accounting conservatism. These firms are incentivized to record losses and expenses sooner rather than later because markets and investors react to negative information to a lesser degree when information is disclosed sooner rather than later (Skinner, 1994).

\section{Regulation}

Similar to the asymmetry in contracting and litigation costs for parties external to the firm, an asymmetry in costs also exists for accounting standard setters and regulators which Watts (2003a, 2003b) terms the regulation explanation of conservatism. The political costs to these non-contracting parties (standard setters and regulators) are higher if firms overstate, rather than understate, net assets because overstatements will be more visible to investors and outsiders. Regulated firms are also more visible because they tend to be larger in size. Examples of regulated firms include banks, insurance companies, utilities, pharmaceuticals, and those in the oil and gas industries. Watts and Zimmerman (1990) state that size has been used as a proxy for political attention. Specific government regulations such as the Securities and Exchange Acts of 1933 and 1934, and more recently, the Sarbanes-Oxley (SOX) Act of 2002, encourage conservatism due to early recognition of revenues and net assets. Conversely, fair value accounting, which encompasses revaluations of net assets, is not considered conservative in nature. In terms of regulation, standard setters and regulators are preferential to accounting conservatism. It has been noted that conservatism has evolved more extensively after the FASB's involvement with financial reporting (Holthausen and Watts, 2001). Regulators and standard setters direct more conservatism by imposing costs or fines for overly aggressive behavior, forcing firms to record losses sooner rather than forgo compliance. In this regard, regulation is 
considered a form of unconditional conservatism. However, recently, standard setters are moving away from conservatism and towards the valuation perspective of accounting. Yet, Watts (2003a) and LaFond and Watts (2008) argue that a decrease in conservatism promulgated by FASB would increase information asymmetry.

\section{Taxation}

Asymmetric recognition of losses and gains due to accounting conservatism in financial reporting can affect taxes paid by firms. Profitable firms can reduce or defer their taxes by decreasing their earnings through the use of accounting conservatism. Taxes are affected because of the link between financial reporting and taxation (Watts, 2003a, 2003b). Accounting principles can be changed which produce a change in tax liability or deferred taxes for firms. Qiang (2007) shows that taxation induces unconditional conservatism. An example of conservative accounting used to decrease current and future taxes is the LIFO inventory costing method, which tends to reduce reported and taxable income.

Hence, the explanations of accounting conservatism afford us an opportunity to assess which of these factors provide value relevance in explaining stock returns and prices. Our research questions are designed as follows:

RQ1: Are the accounting conservatism explanations of contracting, litigation, regulation, and taxation associated with contemporaneous stock returns and prices?

RQ2: How are the accounting conservatism explanations of contracting, litigation, regulation, and taxation associated with contemporaneous stock returns and prices over time?

\section{RESEARCH DESIGN}

Pooled, cross-sectional OLS regressions of the data are conducted to test the first research question presented above by using contemporaneous stock return and price models (Models 1 and 2). The explanatory variables, beyond the conservatism explanations used in both models, are taken from Penman and Zhang (2002). Measures of accounting conservatism, represented by the drivers of contracting, litigation, regulation, and taxation are added to the model as part of the other information dynamics in order to determine their level of value relevance beyond variables generally used in asset pricing models. The models are listed as follows:

$$
\begin{aligned}
& R_{E T}=\alpha+\beta_{1} B_{i t} E T A_{i t}+\beta_{2} \operatorname{LnBTM}_{i t}+\beta_{3} \operatorname{LnTA}_{i t}+\beta_{4} L E V_{i t}+\beta_{5} E P R_{i t}+\beta_{6} \Delta E A R N_{i t}+ \\
& \beta_{7} \text { EPSLOSS }_{i t}+\beta_{8} \text { BUSCYC }_{i t}+\beta_{9}\left(\text { CONTRACT }_{i t}, L_{i t}, R_{i t} G_{i t}, T A X_{i t}\right)+\varepsilon_{i t} \\
& \text { PRICE }_{i t}=\alpha+\beta_{1} \text { BETA }_{i t}+\beta_{2} \text { LnBTM }_{i t}+\beta_{3} \text { LnTA }_{i t}+\beta_{4} \text { LEV }_{i t}+\beta_{5} E P R_{i t}+\beta_{6} \text { EPSLOSS }_{i t}+ \\
& \beta_{7} \text { BUSCYC }_{i t}+\beta_{8}\left(\text { CONTRACT }_{i t}, L I T_{i t}, R E G_{i t}, T A X_{i t}\right)+\varepsilon_{i t}
\end{aligned}
$$

Our second set of tests, following Lev and Zarowin (1999) and Brown et al. (1999), operationalize the proxy for value relevance from the adjusted $\mathrm{R}^{2} \mathrm{~s}$ derived from the above full models for each conservatism driver by fiscal year. The coefficient $\beta_{j}$ estimated from the regression model below represents the trend in accounting conservatism over time (where $j$ represents CONTRACT, LIT, REG, and TAX).

$$
R^{2}{ }_{j t}=\alpha_{j}+\beta_{j} Y E A R_{t}+\varepsilon_{j t}
$$

As a supplement to our second set of tests, we also assess whether the trends in value relevance for the separate four explanations of accounting conservatism vary across time using only the conservatism drivers as the independent variables. This is accomplished by obtaining adjusted $\mathrm{R}^{2}$ s from Models 4 and 5 below for the contemporaneous returns and prices for each conservatism driver by fiscal year. Similarly, we then regress the adjusted $\mathrm{R}^{2} \mathrm{~s}$ on the variable year to derive the coefficient estimate for the time trend using Model (3) above. 


$$
\begin{aligned}
& R T_{i t}=\alpha+\beta_{1}\left(C_{\text {CONTRACT }}, L_{i t}, T_{i t}, R_{i t}, T A X_{i t}\right)+\varepsilon_{i t} \\
& \text { PRICE }_{i t}=\alpha+\beta_{1}\left(C O N T R A C T_{i t}, L I T_{i t}, R E G_{i t}, T A X_{i t}\right)+\varepsilon_{i t}
\end{aligned}
$$

Definitions of the dependent and independent variable measures used in the analysis are listed below. The proxies for the explanations of conservatism are borrowed from Qiang (2007).

$$
\begin{aligned}
& \text { RETURN }_{i t}=\text { Total one-year stock return measured at fiscal year-end (COMPUSTAT Mnemonic TRT1Y) } \\
& \text { for firm } i \text {. } \\
& \text { PRICE }_{i t}=\text { Fiscal year-end close price (COMPUSTAT\# 199) for firm } i . \\
& B E T A_{i t}=\text { Capital asset pricing model (CAPM) beta for firm } i \text {. BETA is estimated from a regression of } \\
& 48 \text { monthly raw returns on the CRSP value-weighted monthly stock returns up to the last } \\
& \text { month of fiscal-year } t \text {. } \\
& \operatorname{LnBTM}_{i t}=\text { The natural logarithm of book to market value of common stock for firm } i \text {. Book-to-market is } \\
& \operatorname{LnTA}_{i t}=\text { Natural logarithm of total assets (COMPUSTAT \#6) for firm } i .{ }^{1} \\
& L E V_{i t}=\text { Leverage, calculated as book value of total assets (COMPUSTAT \#6) to book value of } \\
& \text { common equity (COMPUSTAT \#60) for firm } i \text {. } \\
& E P R_{i t}=\text { Earnings-to-price ratio for firm } i \text {. This variable is calculated as earnings before extraordinary } \\
& \text { items (COMPUSTAT \#18) scaled by year-end price (COMPUSTAT \#199). }{ }^{2} \\
& \triangle E A R N_{i t}=\text { The difference between } \mathrm{EPR}_{i t} \text { and } \mathrm{EPR}_{i t-1} \text {. } \\
& \text { EPSLOSS }_{i t}=\text { Negative earnings per share indicator for firm } i \text { defined as one, if earnings are negative, and } \\
& \text { zero otherwise. } \\
& B U S C Y C_{i t}=\text { Business cycle, represented as one if the U.S. economy for the year is considered to be in a } \\
& \text { contraction period, zero if the economy is considered to be in an expansion period. Data is } \\
& \text { obtained from http://www.nber.org. } \\
& \text { CONTRACT }_{i t}=\text { Equity contracting proxy }+ \text { Debt contracting proxy: The percent of a company's aggregate } \\
& \text { number of shares held by institutions to common shares outstanding (COMPUSTAT } \\
& \text { Mnemonic IOTSHRO) plus the ratio of private long-term debt (COMPUSTAT \#81+\#83+84) } \\
& \text { divided by total long-term debt (COMPUSTAT \#81+\#82+\#83+\#84). } \\
& L I T_{i t}=\text { Litigation proxy: an indicator variable equal to the sum of one, if a firm's auditor } \\
& \text { (COMPUSTAT \#149) is from } 1 \text { to } 8 \text { (which represents a Big-N auditor) plus one if the firm }
\end{aligned}
$$

\footnotetext{
${ }^{1}$ The model of Penman and Zhang (2002) uses market value to control for size. However, their model employs future returns as the dependent variable and we use current returns. Current returns are very close to changes in market value and market value would likely subsume all other variables. For this reason, we use total assets to proxy for firm size.

${ }^{2}$ We do not use the price to earnings ratio provided by COMPUSTAT because the data only dates as far back as 1998 in the current COMPUSTAT database. Instead, we use earnings per share divided by stock price described above for the earnings per share ratio.
} 


\section{SAMPLE SELECTION}

Data for the final sample is obtained from the Research Insight Standard \& Poor's Compustat annual active and research files and the Center for Research in Securities Prices (CRSP) for the period 1993-2009. To mitigate the effect of outliers or extreme observations, the independent variables, except for the indicator variables, are winsorized at the top and bottom $1 \%$ of their respective distributions. After deleting firms with missing observations, our sample consists of 52,904 firm-year observations for the litigation, regulation, and taxation regressions and 38,889 firm-year observations for the contracting regressions. Table 1 reports the descriptive statistics for the variables used in the regression equations.

Table 1

\begin{tabular}{|c|c|c|c|c|c|c|}
\hline \multicolumn{7}{|c|}{ Descriptive Statistics } \\
\hline Variable & $\mathbf{n}$ & Mean & Std. Dev. & Q1(25\%) & Median & Q3 (75\%) \\
\hline RETURN & 52,904 & 0.1873 & 0.7726 & -0.2507 & 0.0474 & 0.3877 \\
\hline PRICE & 52,904 & 21.3153 & 45.6108 & 5.059 & 11.7980 & 23.410 \\
\hline BETA & 52,904 & 1.1896 & 1.0287 & 0.5600 & 1.0385 & 1.6689 \\
\hline LnBTM & 52,904 & -0.7188 & 0.8325 & -1.2118 & -0.6716 & -0.1886 \\
\hline LnTA & 52,904 & 5.6773 & 2.1623 & 4.0783 & 5.5351 & 7.1330 \\
\hline$L E V$ & 52,904 & 2.5915 & 2.6565 & 1.4097 & 1.9161 & 2.7804 \\
\hline$E P R$ & 52,904 & 3.1838 & 19.1400 & -0.3322 & 0.5874 & 2.8673 \\
\hline$\triangle E A R N$ & 52,904 & -0.3301 & 14.1753 & -0.9449 & -0.0002 & 0.8338 \\
\hline EPSLOSS & 52,904 & 0.3190 & 0.4661 & 0.0000 & 0.0000 & 1.0000 \\
\hline$B U S C Y C$ & 52,904 & 0.1165 & 0.3208 & 0.0000 & 0.0000 & 0.0000 \\
\hline CONTRACT & 38,889 & 1.2939 & 0.4536 & 1.0000 & 1.0375 & 1.7394 \\
\hline$L I T$ & 52,904 & 1.1737 & 0.5998 & 1.0000 & 1.0000 & 2.0000 \\
\hline$R E G$ & 52,904 & 0.2198 & 0.4141 & 0.0000 & 0.0000 & 0.0000 \\
\hline$T A X$ & 52,904 & 0.0898 & 68.0005 & 0.4984 & 0.8336 & 0.9887 \\
\hline
\end{tabular}

Table 2 reports the Pearson and Spearman correlation coefficients. The conservatism drivers, except for taxation, are significantly associated with returns and prices. More important, contracting, litigation, and regulation are all positively related to each other, supporting their use as conservatism proxies. We are not surprised by the statistically insignificant relationships with the taxation driver of conservatism because Watts (2003b) states that the evidence related to the taxation driver is weak. Nevertheless, proper analysis involves multivariate testing and analysis, which we perform in Section V.

Table 2

\begin{tabular}{|c|c|c|c|c|c|c|}
\hline \multicolumn{7}{|c|}{ Pearson and Spearman Correlation Matrix } \\
\hline Variables & RETURN & PRICE & CONTRACT & $L I T$ & REG & $T A X$ \\
\hline RETURN & - & $0.0774 * * *$ & $0.0245 * * *$ & $0.0189 * * *$ & $-0.0706^{* * *}$ & -0.0050 \\
\hline PRICE & $0.2758 * * *$ & - & $0.0197 * * *$ & $0.0235 * * *$ & $0.0611 * * *$ & 0.0017 \\
\hline CONTRACT & $0.0483 * * *$ & $0.1216 * * *$ & - & $0.0759 * * *$ & $0.0196^{* * *}$ & -0.0080 \\
\hline LIT & $-0.0091 * *$ & $0.0648 * * *$ & $0.0556 * * *$ & - & $-0.022 * * *$ & $-0.0245^{* * *}$ \\
\hline$R E G$ & $-0.0751 * * *$ & $0.1508 * * *$ & $0.0196 * * *$ & $-0.0214 * * *$ & - & -0.0002 \\
\hline$T A X$ & $0.0166 * * *$ & $0.0450 * * *$ & -0.0016 & $0.0428 * * *$ & 0.0027 & - \\
\hline
\end{tabular}

Pearson correlation coefficients are reported above the diagonal and Spearman correlation coefficients are reported below the diagonal. Significance levels are based on two-tailed tests. $*$, **, *** are significance levels at the $10 \%, 5 \%$, and $1 \%$ levels, respectively.

Table 3, Panel A, provides the sample distribution by industry based on the 48-industry specifications from Fama and French (1997). The largest composition of firms is from the business services sector, representing 12.41 percent of the sample. The next largest industry group is the electronic sector, representing $7.42 \%$ of the sample. Table 3, Panel B, shows that over time, each year contains a nearly equal proportionate number of firm-year observations which suggests that the sample is not biased to certain years. 
Table 3

\begin{tabular}{|c|c|c|c|c|c|}
\hline \multicolumn{6}{|c|}{ Panel A: Sample Distribution by Industry } \\
\hline Industry Description & Firm-Year Obs. & Percent & Industry Description & Firm-Year Obs. & Percent \\
\hline Apparel & 845 & 1.60 & Machinery & 2,306 & 4.36 \\
\hline Automobiles and Trucks & 882 & 1.67 & Measuring and Cont. & 1,442 & 2.73 \\
\hline Business Services & 6,568 & 12.41 & Medical Equipment & 1,948 & 3.68 \\
\hline Business Supplies & 829 & 1.57 & Personal Services & 584 & 1.10 \\
\hline Chemicals & 1,121 & 2.12 & Petroleum and Nat. Gas & 2,579 & 4.87 \\
\hline Computers & 2,520 & 4.76 & Pharmaceuticals Prod. & 3,510 & 6.63 \\
\hline Construction & 722 & 1.36 & Restaurants/Hotels & 1,149 & 2.17 \\
\hline Construction Materials & 1,018 & 1.92 & Retail & 2,902 & 5.49 \\
\hline Consumer Goods & 952 & 1.80 & Steel Works, etc. & 842 & 1.59 \\
\hline Electrical Equipment & 677 & 1.28 & Telecommunications & 1,883 & 3.56 \\
\hline Electronic Equipment & 3,925 & 7.42 & Transportation & 1,575 & 2.98 \\
\hline Entertainment & 820 & 1.55 & Utilities & 2,455 & 4.64 \\
\hline Food Products & 1,042 & 1.97 & Wholesale & 2,018 & 3.81 \\
\hline \multirow[t]{2}{*}{ Healthcare } & 995 & 1.88 & Others(less than $1 \%$ ) & $\underline{4795}$ & $\underline{9.08}$ \\
\hline & & & Total & 52,904 & 100.00 \\
\hline \multicolumn{6}{|c|}{ Panel B: Sample Distribution by Year } \\
\hline Year & Firm-Year Obs. & Percent & Year & Firm-Year Obs. & Percent \\
\hline 1993 & 1,559 & 2.95 & 2002 & 3,430 & 6.48 \\
\hline 1994 & 2,952 & 5.58 & 2003 & 3,325 & 6.28 \\
\hline 1995 & 3,205 & 6.06 & 2004 & 3,190 & 6.03 \\
\hline 1996 & 3,397 & 6.42 & 2005 & 3,017 & 5.70 \\
\hline 1997 & 3,555 & 6.72 & 2006 & 2,916 & 5.51 \\
\hline 1998 & 3,693 & 6.98 & 2007 & 2,781 & 5.26 \\
\hline 1999 & 3,560 & 6.73 & 2008 & 2,768 & 5.23 \\
\hline 2000 & 3,414 & 6.45 & 2009 & $\underline{2,747}$ & $\underline{5.20}$ \\
\hline 2001 & 3,395 & 6.42 & Total & $5 \overline{2,904}$ & $10 \overline{000}$ \\
\hline
\end{tabular}

\section{EMPIRICAL RESULTS}

Table 4, Panel A, presents the results of the OLS regressions of contemporaneous returns on the four explanations of accounting conservatism and control variables. The coefficients on the conservatism explanations of contracting (CONTRACT), litigation (LIT), and regulation $(R E G)$ are negative and equal to $-0.0223,-0.0530$ and -0.0955 , respectively. These coefficients are significant at the one percent level. We interpret the negative relations as suggestive that firms that use more accounting conservatism require a lower cost of capital due to conservatism's qualitative feature of reducing information asymmetry and moral hazard. For instance, a recent study by García Lara et al. (2011) finds future returns are negatively related to conditional conservatism and explain this association as due to a reduction in information uncertainty. Even though we do not directly examine conditional conservatism, the explanations of conservatism are related to conditional conservatism.

Our findings are also similar in spirit to Ahmed at al. 2002. In their study, they explain that firms with higher bondholder-shareholder conflicts, as proxied by lower return on assets, higher volatility of earnings, and greater leverage, exhibit higher levels of accounting conservatism. In this manner, firms utilize accounting conservatism to mitigate agency problems of the firm. Dimitrov and Jain (2008) also document a significantly negative relation between changes in financial leverage and stock returns, revealing that changes in leverage are associated with lower returns and are value relevant. They define leverage as deterioration in performance which causes firms to use the debt market versus the equity market because the equity market is associated with higher costs. The negative and statistically significant relation between leverage and stock prices also implies that the change in financial leverage is still impounded in stock prices in a timely manner.

Next, Table 4, Panel B, for the price regressions, shows that the coefficients on CONTRACT and LIT are also negative and significant. However, the coefficient on $R E G$ is positive and statistically significant (coefficient $=$ $5.6865, p$-value $=0.001)$. A possible explanation for this relation is that since accounting conservatism leads to a decline in relevant information (or is negatively biased), and lower income over time, the relationship between prices and accounting conservatism is positive. This explanation suggests that regulation as a driver for 
conservatism is still impounded into prices and serves a valuable role, but this information may not be as timely as revealed from the return regression. Therefore, the market assimilates the information content of regulation in a timelier manner as an explanation of accounting conservatism more so in contemporaneous stock returns than in prices.

For the variable representing taxation $(T A X)$, in the return regressions (Table 4, Panel A), the coefficient on $T A X$ is not statistically significant. This finding is consistent with the correlations of Table 2 , which also show an insignificant relationship of the taxation explanation of conservatism and stock returns. For the price regressions, the coefficient for taxes is positive and statistically significant. Overall, these different relations for the taxation driver of conservatism show that while taxes are value relevant in impounding the information in prices, the information is not timely for returns. However, caution is advised in interpreting the results for the taxation driver because the evidence on this explanation is weak (Watts, 2003b).

Table 4

OLS Regressions of Returns and Prices on the Explanations of Accounting Conservatism and Control Variables

\begin{tabular}{|c|c|c|c|c|}
\hline \\
\hline \multicolumn{5}{|c|}{ (1) } \\
\hline & $\begin{array}{l}\text { Coefficient } \\
(t \text {-statistic) }\end{array}$ & $\begin{array}{l}\text { Coefficient } \\
\text { ( } t \text {-statistic) }\end{array}$ & $\begin{array}{l}\text { Coefficient } \\
\text { ( } t \text {-statistic) }\end{array}$ & $\begin{array}{l}\text { Coefficient } \\
\text { ( } t \text {-statistic) }\end{array}$ \\
\hline \multirow[t]{2}{*}{ Intercept } & 0.1667 & 0.1611 & 0.1286 & 0.1205 \\
\hline & $(10.08)^{* * *}$ & $(13.02)^{* * *}$ & $(11.25)^{* * *}$ & $(10.54)^{* * *}$ \\
\hline \multirow[t]{2}{*}{ BETA } & 0.0360 & 0.0346 & 0.0316 & 0.0303 \\
\hline & $(6.71)^{* * *}$ & $(7.93)^{* * *}$ & $(7.34)^{* * *}$ & $(7.03)^{* * *}$ \\
\hline \multirow[t]{2}{*}{$\operatorname{LnBTM}$} & -0.3073 & -0.3238 & -0.3158 & -0.3173 \\
\hline & $(-52.88) * * *$ & $(-64.64) * * *$ & $(-63.58) * * *$ & $(-63.80) * * *$ \\
\hline \multirow[t]{2}{*}{$L n T A$} & -0.0116 & -0.0075 & -0.0077 & -0.0099 \\
\hline & $(-5.65) * * *$ & $(-4.22)^{* * *}$ & $(-4.32)^{* * *}$ & $(-5.59)^{* * *}$ \\
\hline \multirow{2}{*}{$L E V$} & -0.0137 & -0.0159 & 0.0146 & -0.0145 \\
\hline & $(-7.93) * * * *$ & $(-10.01)^{* * *}$ & $(-9.28) * * *$ & $(-9.19)^{* * *}$ \\
\hline \multirow[t]{2}{*}{$E P R$} & -0.0027 & -0.0029 & -0.0028 & -0.0028 \\
\hline & $(-11.13) * * *$ & $(-12.52) * * *$ & $(-12.37)^{* * *}$ & $(-12.19) * * *$ \\
\hline \multirow[t]{2}{*}{$\triangle E A R N$} & 0.0058 & 0.0072 & 0.0072 & 0.0072 \\
\hline & $(13.14)^{* * *}$ & $(17.88)^{* * *}$ & $(17.77)^{* * *}$ & $(17.75)^{* * *}$ \\
\hline \multirow[t]{2}{*}{ EPSLOSS } & -0.2133 & -0.2061 & -0.2172 & -0.2127 \\
\hline & $(-22.39) * * *$ & $(-24.87) * * *$ & $(-26.33) * * *$ & $(-25.75) * * *$ \\
\hline \multirow[t]{2}{*}{$B U S C Y C$} & -0.1803 & -0.2100 & -0.1952 & -0.2097 \\
\hline & $(-17.28) * * *$ & $(-23.99) * * *$ & $(-22.12) * * *$ & $(-23.97) * * *$ \\
\hline CONTRACT & $\begin{array}{l}-0.0223 \\
(-3.05) * * * *\end{array}$ & & & \\
\hline$L I T$ & & $\begin{array}{l}-0.0530 \\
(-9.08) * * *\end{array}$ & & \\
\hline$R E G$ & & & $\begin{array}{l}-\mathbf{0 . 0 9 5 5} \\
(-14.07)^{* * * *}\end{array}$ & \\
\hline$T A X$ & & & & $\begin{array}{l}0.0001 \\
(0.81)\end{array}$ \\
\hline $\mathrm{n}$ & 38,879 & 52,904 & 52,904 & 52,904 \\
\hline Adj. $\mathrm{R}^{2}$ & 16.31 & 17.36 & 17.46 & 17.21 \\
\hline
\end{tabular}


Panel B: Dependent Variable: Price

\begin{tabular}{|c|c|c|c|c|}
\hline (1) & $\begin{array}{c}(2) \\
\text { Coefficient } \\
(t \text {-statistic) }\end{array}$ & $\begin{array}{l}(3) \\
\text { Coefficient } \\
(t \text {-statistic })\end{array}$ & $\begin{array}{l}\quad(4) \\
\text { Coefficient } \\
(t \text {-statistic) }\end{array}$ & $\begin{array}{l}\quad(5) \\
\text { Coefficient } \\
(t \text {-statistic) }\end{array}$ \\
\hline Intercept & $\begin{array}{l}-0.8090 \\
(-0.79)\end{array}$ & $\begin{array}{l}-1.9445 \\
(-2.42)^{* *}\end{array}$ & $\begin{array}{l}-3.6955 \\
(-5.00) * * *\end{array}$ & $\begin{array}{l}-3.2361 \\
(-4.38)^{* * *}\end{array}$ \\
\hline BETA & $\begin{array}{l}-0.5038 \\
(-1.54)\end{array}$ & $\begin{array}{l}-0.5748 \\
(-2.33)^{* *}\end{array}$ & $\begin{array}{l}-0.7942 \\
(-3.21)^{* * *}\end{array}$ & $\begin{array}{l}-0.7103 \\
(-2.88) * * *\end{array}$ \\
\hline LnBTM & $\begin{array}{l}-9.9909 \\
(-24.43)^{* * *}\end{array}$ & $\begin{array}{l}-9.4718 \\
(-29.16) * * *\end{array}$ & $\begin{array}{l}-9.3394 \\
(-28.94)^{* * *}\end{array}$ & $\begin{array}{l}-9.2715 \\
(-28.72) * * *\end{array}$ \\
\hline LnTA & $\begin{array}{l}3.7531 \\
(25.92) * * *\end{array}$ & $\begin{array}{l}3.6383 \\
(30.24) * * *\end{array}$ & $\begin{array}{l}3.4332 \\
(28.61)^{* * *}\end{array}$ & $\begin{array}{l}3.5641 \\
(29.76)^{* * *}\end{array}$ \\
\hline$L E V$ & $\begin{array}{l}-0.8056 \\
(-7.32)^{* * *}\end{array}$ & $\begin{array}{l}-0.6915 \\
(-6.13)^{* * *}\end{array}$ & $\begin{array}{l}-0.6406 \\
(-5.73) * * *\end{array}$ & $\begin{array}{l}-0.6465 \\
(-5.78) * * *\end{array}$ \\
\hline$E P R$ & $\begin{array}{l}-0.0902 \\
(-9.11)^{* * *}\end{array}$ & $\begin{array}{l}-0.0673 \\
(-7.83)^{* * *}\end{array}$ & $\begin{array}{l}-0.0629 \\
(-7.37)^{* * *}\end{array}$ & $\begin{array}{l}-0.0654 \\
(-7.61)^{* * *}\end{array}$ \\
\hline EPSLOSS & $\begin{array}{l}2.023 \\
(3.10)^{* * * *}\end{array}$ & $\begin{array}{l}2.2669 \\
(4.26)^{* * * *}\end{array}$ & $\begin{array}{l}2.3238 \\
(4.38)^{* * * *}\end{array}$ & $\begin{array}{l}2.0648 \\
(3.90)^{* * * *}\end{array}$ \\
\hline BUSCYC & $\begin{array}{l}-1.846 \\
(-2.97)^{* * *}\end{array}$ & $\begin{array}{l}-2.3951 \\
(-4.79)^{* * *}\end{array}$ & $\begin{array}{l}-3.2548 \\
(-6.35)^{* * *}\end{array}$ & $\begin{array}{l}-2.3810 \\
(4.76)^{* * *}\end{array}$ \\
\hline CONTRACT & $\begin{array}{l}-2.552 \\
(-5.64) * * *\end{array}$ & & & \\
\hline LIT & & $\begin{array}{l}-1.6682 \\
(-5.02) * * * *\end{array}$ & & \\
\hline$R E G$ & & & $\begin{array}{l}5.6865 \\
(11.58)^{* * * *}\end{array}$ & \\
\hline$T A X$ & & & & $\begin{array}{l}0.0039 \\
(9.02)^{* * * *}\end{array}$ \\
\hline $\mathrm{n}$ & 38,879 & 52,904 & 52,904 & 52,904 \\
\hline Adj. $\mathrm{R}^{2}$ & 5.14 & 4.92 & 5.13 & 4.88 \\
\hline
\end{tabular}

The standard errors are clustered standard errors which are White (1980) standard errors adjusted for firm and year. Significance levels are based on two-tailed tests. *, **, *** are significance levels at $10 \%, 5 \%$, and $1 \%$ levels, respectively.

Table 5, Panels $\mathrm{A}$ and $\mathrm{B}$, report the results of the adjusted $\mathrm{R}^{2} \mathrm{~s}$ (derived from the full cross-sectional regressions of Models (1) and (2) provided in Section III), regressed on year, for each respective conservatism driver. The resulting coefficient, $\beta$, represents the trend in value relevance over time. Panel A, provides the results of using the adjusted $\mathrm{R}^{2}$ s from Model 1 . We find no suggestion that value relevance over time has changed because the coefficient, $\beta$, is not significant for any of the conservatism drivers. The adjusted $\mathrm{R}^{2}$ is negative, most likely due to the small number of observations $(n=17)$ which represents the sample years 1993-2009.

Panel B provides the results of using the adjusted $\mathrm{R}^{2} \mathrm{~s}$ from Model 2. The coefficient, $\beta$, on each of drivers of CONTRACT, LIT, REG, and TAX, is positive and statistically significant. Therefore, in contrast to Panel A, the value relevance of these drivers has been increasing. That is, over time we do find that value relevance has changed and is impounded into stock prices. Overall, the results illustrated in these two panels differ from Lev and Zarowin (1999), and appear to complement Balachandran and Mohanram (2011) who indicate that there is no decline in value relevance due to accounting conservatism.

Additionally, to isolate whether the conservatism drivers alone are value relevant over time, without including the other risk measures used in the full model, we report the results of the adjusted $\mathrm{R}^{2}$, derived from the simple model of returns and prices regressed on each of the conservatism drivers separately by year in Panels $\mathrm{C}$ and $\mathrm{D}$ (Models 4 and 5, respectively). In Panel C, for the return regressions, we again find that the trend of the drivers has no effect on value relevance. In Panel D, our results indicate that over time, the contracting and regulation explanations for accounting conservatism are associated with an increase in value relevance with respect to prices.

Reconciling the results in Tables 4 and 5, our analysis provides evidence that the level of contracting, litigation, and regulation appear to be generally more consistent in terms of value relevance by the nature of their associations with contemporaneous stock returns and prices than the taxation explanation. In terms of the time trend, 
we find no evidence that there is a decline in value relevance of the four explanations of conservatism and, in fact, there is actually an increase in the trend in accounting conservatism with respect to the drivers of contracting and regulation.

Table 5

Temporal Association of $\mathbf{R}^{2}$ from OLS Regressions with Respect to Each Conservatism Driver on Time

\begin{tabular}{|c|c|c|c|c|}
\hline \multicolumn{5}{|c|}{ Panel A: $\mathbf{R}^{2}$ from Return Regression (Model 1) Regressed on Year } \\
\hline & $\alpha$ & $\beta$ & Adj. $\mathrm{R}^{2}$ & $\mathrm{n}$ \\
\hline \multicolumn{5}{|c|}{ CONTRACT } \\
\hline estimate & -5.8375 & 0.0030 & & \\
\hline$t$-statistic & $(-0.72)$ & $(0.75)$ & -2.86 & 17 \\
\hline \multicolumn{5}{|l|}{$\underline{L I T}$} \\
\hline$\overline{\text { estimate }}$ & -7.2781 & 0.0037 & & \\
\hline$t$-statistic & $(-0.92)$ & $(0.94)$ & -0.69 & 17 \\
\hline \multicolumn{5}{|l|}{$\underline{R E G}$} \\
\hline$\overline{\text { estimate }}$ & -6.6154 & 0.0034 & & \\
\hline$t$-statistic & $(-0.82)$ & $(0.85)$ & -1.79 & 17 \\
\hline \multicolumn{5}{|l|}{$\underline{T A X}$} \\
\hline$\overline{\text { estimate }}$ & -6.1247 & 0.0032 & & \\
\hline$t$-statistic & $(0.76)$ & $(0.78)$ & -2.50 & 17 \\
\hline \multicolumn{5}{|c|}{ Panel B: $\mathbf{R}^{2}$ from Price Regression (Model 2) Regressed on Year } \\
\hline & $\alpha$ & $\beta$ & Adj. $R^{2}$ & $\mathrm{n}$ \\
\hline \multicolumn{5}{|c|}{ CONTRACT } \\
\hline estimate & -23.9719 & 0.0120 & & \\
\hline$t$-statistic & $(-6.23)^{* * *}$ & $(6.26)^{* * * *}$ & 70.45 & 17 \\
\hline \multicolumn{5}{|l|}{$\underline{L I T}$} \\
\hline$\overline{\text { estimate }}$ & -28.4653 & 0.0143 & & \\
\hline$t$-statistic & $(-6.47)^{* * *}$ & $(6.50)^{* * * *}$ & 72.03 & 17 \\
\hline \multicolumn{5}{|l|}{$\underline{R E G}$} \\
\hline$\overline{\text { estimate }}$ & -27.4130 & 0.0138 & & \\
\hline$t$-statistic & $(-6.20)^{* * *}$ & $(6.22)^{* * * *}$ & 70.22 & 17 \\
\hline \multicolumn{5}{|l|}{$\underline{T A X}$} \\
\hline estimate & -27.3687 & 0.0137 & & \\
\hline$t$-statistic & $(-6.16)^{* * *}$ & $(6.18)^{* * * *}$ & 69.90 & 17 \\
\hline \multicolumn{5}{|c|}{ Panel C: $\mathbf{R}^{2}$ from Return Regression (Model 4) Regressed on Year } \\
\hline & $\alpha$ & $\beta$ & Adj. $\mathrm{R}^{2}$ & $\mathrm{n}$ \\
\hline \multicolumn{5}{|c|}{ CONTRACT } \\
\hline estimate & 0.1485 & -0.0000 & & \\
\hline$t$-statistic & $(0.39)$ & $(-0.38)$ & -5.63 & 17 \\
\hline \multicolumn{5}{|l|}{$\underline{L I T}$} \\
\hline estimate & 0.5482 & -0.0003 & & \\
\hline$t$-statistic & $(0.69)$ & $(-.68)$ & -3.45 & 17 \\
\hline \multicolumn{5}{|l|}{$\underline{R E G}$} \\
\hline estimate & -0.4621 & 0.0002 & & \\
\hline$t$-statistic & $(-1.54)$ & $(1.55)$ & 8.12 & 17 \\
\hline \multicolumn{5}{|l|}{$\underline{T A X}$} \\
\hline estimate & 0.0041 & -0.0000 & & \\
\hline$t$-statistic & $(0.04)$ & $(-0.04) * * *$ & -6.67 & 17 \\
\hline
\end{tabular}




\begin{tabular}{|c|c|c|c|c|}
\hline \multicolumn{5}{|c|}{ Panel D: $\mathbf{R}^{2}$ from Price Regression (Model 5) Regressed on Year } \\
\hline \multirow{2}{*}{\multicolumn{5}{|c|}{ CONTRACT }} \\
\hline$\frac{\text { CUNINACI }}{\text { estimate }}$ & & & & \\
\hline$t$-statistic & $\begin{array}{l}-0.5121 \\
(-3.18)^{* * *}\end{array}$ & $\begin{array}{l}0.0003 \\
(3.19)^{* * * *}\end{array}$ & 36.52 & 17 \\
\hline \multicolumn{5}{|l|}{$L I T$} \\
\hline estimate & -0.0869 & 0.0000 & & \\
\hline$t$-statistic & $(-0.39)$ & $(0.40)$ & -5.52 & 17 \\
\hline \multicolumn{5}{|l|}{$\underline{R E G}$} \\
\hline estimate & -2.4681 & 0.0012 & & \\
\hline$t$-statistic & $(-2.27)^{* *}$ & $(2.28)^{* *}$ & 20.78 & 17 \\
\hline \multicolumn{5}{|l|}{$\underline{T A X}$} \\
\hline estimate & 0.6570 & -0.0003 & & \\
\hline$t$-statistic & $(1.40)$ & $(-1.40)$ & 5.64 & 17 \\
\hline
\end{tabular}

In Panels A and B, the $\mathrm{R}^{2}$ s are obtained from Models (1) and (2) for each firm and regressed in the cross-section on the variable year, which includes each of the explanations representing conservatism for the 17 year period. The $\beta$ coefficient, derived from the regression models, represents the trend in value relevance for all variables including earnings, book values, conservatism explanations, and risk factors. Panels $\mathrm{C}$ and $\mathrm{D}$ report the separate regressions of returns and prices on only the conservatism drivers over time. Significance levels are based on two-tailed tests. *,**, *** are significance levels at the $10 \%, 5 \%$, and $1 \%$ levels, respectively.

\section{SENSITIVITY TESTS}

Our results are robust to the Fama-Macbeth (1973) procedure. Table 6, Panel A, illustrates the results of these regressions of returns on the four explanations of accounting conservatism and control variables. For the contracting, litigation, and regulation explanations of conservatism, the coefficients are statistically significant and negative at $-0.0282,-0.0545$ and -0.0590 , respectively. Table 6 , Panel $\mathrm{B}$, shows that for the price regressions, the coefficients on the contracting and litigation explanations are statistically significant and negative at -2.271 and -2.8431 , respectively. The variable representing regulation is positive and significant (coefficient $=5.6865, p$-value $=0.001$ ). These results continue to provide evidence that the level of contracting, litigation, and regulation are significantly associated with returns and prices, unlike the explanation for taxation.

In another sensitivity test, firms with standard industrial classification codes between 6000-6999 and 49004949 are deleted as these represent firms in the financial, insurance, and regulated industries that may be subject to different reporting requirements. In untabulated results, our findings still hold. Next, we also take into account research and development expenses $(\mathrm{R} \& \mathrm{D})$ as prior literature has indicated that the decline in value relevance may be due to market valuations in the new economy (Core et al. 2003) where there exists the inability of the market to assimilate information in research and development measures. In untabulated results, our findings remain robust to the inclusion of the R\&D control variable. 
Table 6

Fama-MacBeth (1973) Regressions of Returns and Prices on the Explanations of Accounting Conservatism and Control Variables

\begin{tabular}{|c|c|c|c|c|}
\hline \multicolumn{5}{|c|}{ Panel A: Dependent Variable : Return } \\
\hline (1) & (2) & (3) & (4) & $(5)$ \\
\hline & $\begin{array}{l}\text { Coefficient } \\
(t \text { - statistic) }\end{array}$ & $\begin{array}{l}\text { Coefficient } \\
(t \text {-statistic })\end{array}$ & $\begin{array}{l}\text { Coefficient } \\
(t \text {-statistic })\end{array}$ & $\begin{array}{l}\text { Coefficient } \\
(t \text {-statistic })\end{array}$ \\
\hline Intercept & 0.2116 & 0.1762 & 0.1592 & 0.1509 \\
\hline & $(4.02) * * *$ & $(3.02) * * *$ & $(2.97)^{* * *}$ & $(2.77)^{* * * *}$ \\
\hline BETA & 0.0325 & 0.0299 & 0.0242 & 0.0245 \\
\hline & $(1.01)$ & $(0.97)$ & $(0.79)$ & $(0.80)$ \\
\hline LnBTM & -0.2793 & -0.2973 & -0.2895 & -0.2899 \\
\hline & $(-11.23)^{* * *}$ & $(-12.02) * * *$ & $(11.60)^{* * *}$ & $(-11.64) * * *$ \\
\hline LnTA & -0.0187 & -0.0122 & -0.0154 & -0.0165 \\
\hline & $(-3.40)^{* * *}$ & $(-2.07)^{*}$ & $(-2.58)^{* *}$ & $(-2.77)^{* *}$ \\
\hline$L E V$ & -0.0105 & -0.0133 & -0.0115 & -0.0111 \\
\hline & $(-3.46)^{* * * *}$ & $(-4.47)^{* * *}$ & $(-3.74) * * *$ & $(-3.56) * * *$ \\
\hline$E P S$ & -0.0018 & -0.0020 & -0.0019 & -0.0018 \\
\hline & $(-3.91)^{* *}$ & $(-3.78) * * *$ & $(-3.55)^{* * *}$ & $(-3.46) * * *$ \\
\hline$\triangle E A R N$ & 0.0037 & 0.0050 & 0.0049 & 0.0049 \\
\hline & $(5.15)^{* * *}$ & $(6.20)^{* * *}$ & $(6.16)^{* * *}$ & $(6.13)^{* * *}$ \\
\hline EPSLOSS & -0.2460 & -0.2402 & -0.2512 & -0.2476 \\
\hline & $(-11.41)^{* * *}$ & $(-11.67)^{* * *}$ & $(-13.27)^{* * *}$ & $(-12.11)^{* * *}$ \\
\hline CONTRACT & $\begin{array}{l}-0.0282 \\
(-1.78) * *\end{array}$ & & & \\
\hline$L I T$ & & $\begin{array}{l}-0.0545 \\
(-4.29) * * *\end{array}$ & & \\
\hline$R E G$ & & & $\begin{array}{l}-0.0590 \\
(-4.81)^{* * *}\end{array}$ & \\
\hline$T A X$ & & & & $\begin{array}{l}-0.0043 \\
(-1.29)\end{array}$ \\
\hline $\mathrm{n}$ & 17 & 17 & 17 & 17 \\
\hline Avg. Adj. $\mathrm{R}^{2}$ & 23.10 & 24.10 & 23.80 & 23.80 \\
\hline
\end{tabular}

Panel B: Dependent Variable: Price

\begin{tabular}{|c|c|c|c|c|}
\hline (1) & $\begin{array}{c}(2) \\
\text { Coefficient } \\
(t \text {-statistic })\end{array}$ & $\begin{array}{c}(3) \\
\text { Coefficient } \\
(t \text {-statistic) }\end{array}$ & $\begin{array}{c}(4) \\
\text { Coefficient } \\
(t \text {-statistic })\end{array}$ & $\begin{array}{c}(5) \\
\text { Coefficient } \\
(t-\text { statistic })\end{array}$ \\
\hline Intercept & $\begin{array}{l}-3.5864 \\
(-1.69)\end{array}$ & $\begin{array}{l}-4.0513 \\
(-1.78)^{*}\end{array}$ & $\begin{array}{l}-6.8971 \\
(-3.36)^{* *}\end{array}$ & $\begin{array}{l}-6.6887 \\
(-3.43)^{* *}\end{array}$ \\
\hline BETA & $\begin{array}{l}-0.1636 \\
(-0.32)\end{array}$ & $\begin{array}{l}0.1440 \\
(0.27)\end{array}$ & $\begin{array}{l}-0.1685 \\
(-0.34)\end{array}$ & $\begin{array}{l}-0.1656 \\
(0.31)\end{array}$ \\
\hline LnBTM & $\begin{array}{l}-8.9629 \\
(-13.13) * * *\end{array}$ & $\begin{array}{l}-8.7380 \\
(-14.86) * * *\end{array}$ & $\begin{array}{l}-8.5563 \\
(-14.21)^{* * *}\end{array}$ & $\begin{array}{l}-8.4042 \\
(-14.07) * * *\end{array}$ \\
\hline LnTA & $\begin{array}{l}4.1373 \\
(9.57)^{* * *}\end{array}$ & $\begin{array}{l}4.1039 \\
(9.12)^{* * *}\end{array}$ & $\begin{array}{l}3.9249 \\
(9.43)^{* * * *}\end{array}$ & $\begin{array}{l}3.9876 \\
(9.71)^{* * *}\end{array}$ \\
\hline$L E V$ & $\begin{array}{l}-0.8489 \\
(-5.81)^{* * * *}\end{array}$ & $\begin{array}{l}-0.7492 \\
(-4.95)^{* * *}\end{array}$ & $\begin{array}{l}-0.6843 \\
(-4.79)^{* * *}\end{array}$ & $\begin{array}{l}-0.7056 \\
(-5.03) * * *\end{array}$ \\
\hline$E P R$ & $\begin{array}{l}-0.1409 \\
(-7.47)^{* * * *}\end{array}$ & $\begin{array}{l}-0.1252 \\
(-6.60)^{* * * *}\end{array}$ & $\begin{array}{l}-0.1178 \\
(-6.36)^{* * *}\end{array}$ & $\begin{array}{l}-0.1240 \\
(-6.55)^{* * *}\end{array}$ \\
\hline EPSLOSS & $\begin{array}{l}1.5689 \\
(.99)\end{array}$ & $\begin{array}{l}2.3293 \\
(1.56)\end{array}$ & $\begin{array}{l}2.0958 \\
(1.47)\end{array}$ & $\begin{array}{l}2.1154 \\
(1.39)\end{array}$ \\
\hline CONTRACT & $\begin{array}{l}-\mathbf{2 . 2 7 1 2} \\
(-3.35) * * *\end{array}$ & & & \\
\hline$L I T$ & & $\begin{array}{l}-2.8431 \\
(-6.69)^{* * * *}\end{array}$ & & \\
\hline$R E G$ & & & $\begin{array}{l}7.2943 \\
(3.48)^{* * *}\end{array}$ & \\
\hline$T A X$ & & & & $\begin{array}{l}0.8835 \\
(1.22)\end{array}$ \\
\hline $\mathrm{n}$ & 17 & 17 & 17 & 17 \\
\hline Avg. Adj. $R^{2}$ & 8.40 & 9.1 & 9.2 & 9.0 \\
\hline
\end{tabular}

Avg. Adj. $R^{2}$ 8.40 9.2 9.0

Results are based on 17 annual Fama-MacBeth (1973) regressions from 1993-2009. Significance levels are based on two-tailed tests. *, $* *, * * *$ are significance levels at the $10 \%, 5 \%$, and $1 \%$ levels, respectively. 


\section{SUMMARY AND CONCLUSION}

This study examines whether the four explanations of conservatism: contracting, litigation, regulation, and taxation are reflected in stock returns and prices. Our second set of tests examines changes in value relevance over time, determined by the adjusted $\mathrm{R}^{2}$ regressed on year, that can be attributed to each of these explanations of conservatism.

We find that the level of contracting, litigation, and regulation drivers of conservatism are related to contemporaneous stock returns and prices at statistically significant levels. We interpret our results as suggesting that the contracting, litigation, and regulation drivers of conservatism do contain value relevant information. We find less evidence for the explanation of the level of taxation being associated with value relevance. Moreover, we find no evidence that there is a decline in value relevance. In fact, the value relevance for the explanations of contracting and regulation actually increase using the data in our study.

In summary, our results suggest that the explanations for accounting conservatism are distinct from one another, especially taxation, compared to the other three. By operationalizing the explanations of accounting conservatism and articulating their value relevance, the results of our study suggest that disclosure of the effects of these components of conservatism would provide insights to standard setters, a view which parallels with Barth et al. 2001. While conservatism per se is not a stated part of the FASB conceptual framework, our study adds to the literature by showing that through the lens of explaining stock returns and prices, the explanations of accounting conservatism are value relevant.

As with all studies relating to accounting conservatism, there is the limitation of a suitable proxy for accounting conservatism as it is not directly observable. We rely mostly on the proxies used by Qiang (2007) for the explanations of accounting conservatism since there is very little research on operationalizing these drivers. In addition, even though the models we use are derived from prior literature, it is possible that there are omitted variables. We save for future research the further examination of whether the explanations for accounting conservatism are actually priced risk factors.

\section{ACKNOWLEDGEMENT}

The first author wishes to acknowledge a Research Professorship grant funded by Graduate Studies and Research, Youngstown State University.

\section{AUTHOR INFORMATION}

Karin A. Petruska, Ph.D., CPA, received her Ph.D. in Accounting from Kent State University. She is an Assistant Professor in the Lariccia School of Accounting and Finance, Williamson College of Business Administration, Youngstown State University. Her research projects include accounting conservatism, fraudulent financial reporting, earnings quality and disclosure, analyst following, and international accounting. Contact information: Karin A. Petruska, Ph.D., Lariccia School of Accounting and Finance, Williamson College of Business Administration, Youngstown State University, One University Plaza, Youngstown, OH 44555 USA. Tel.: (330) 941-1876; Fax: (330) 941-1459; E-mail: kapetruska@ysu.edu (Corresponding author)

Gulraze Wakil, Ph.D., CGA received his Ph.D. in Accounting from Kent State University. He is an Assistant Professor in the Sprott School of Business at Carleton University, Canada. His research projects include accounting conservatism, accounting and capital markets, time series forecasting, and international accounting. His teaching interests include all areas of accounting. Contact information: Gulraze Wakil, Ph.D., Sprott School of Business, Carleton University, 1015 Dunton Tower, 1125 Colonel By Drive, Ottawa, ON K1S 5B6 Canada. Phone: (613) 520-2600 x1759; Fax: (613) 520-4427; E-mail: gulraze_wakil@carleton.ca 


\section{REFERENCES}

1. Ahmed, A.S., Billings, B.K., Morton, R.M., Stanford-Harris, M. (2002). The role of accounting conservatism in mitigating bondholder-shareholder conflicts over dividend policy and in reducing debt costs. The Accounting Review, 77(4): 867-890.

2. Balachandran, S., and Mohanram, P. (2011). Is the decline in the value relevance of accounting driven by increased conservatism? Review of Accounting Studies, 16(2): 272-301.

3. Ball, R., Robin, A., and Sadka, G. (2008). Is financial reporting shaped by equity markets or by debt markets? An international study of timeliness and conservatism. Review of Accounting Studies, 13(2-3): 168-205.

4. Barth, M.E., Beaver, W.H., and Landsman, W.R. (2001). The relevance of the value relevance literature of financial standard setting: Another view. Journal of Accounting and Economics, 31(1-3): 77-104.

5. Basu, S. (1997). The conservatism principle and the asymmetric timeliness of earnings. Journal of Accounting and Economics, 24(1): 3-37.

6. Beatty, A., Weber, J., Yu, J.J. (2008). Conservatism and debt. Journal of Accounting and Economics, 45(23): $154-174$.

7. Beaver, W. (2002). Perspectives on recent capital market research. The Accounting Review, 77(2): 453-474.

8. Beaver, W.H., and Ryan, S.G. (2005). Conditional and unconditional conservatism: Concepts and modeling. Review of Accounting Studies, 10(2-3): 269-309.

9. Bliss, J.H. (1924). Management through accounts. New York, New York: The Ronald Press Co.

10. Brown, W.D., He, H. and Teitel, K. (2006). Conditional conservatism and the value relevance of accounting earnings: An international study. European Accounting Review, 15(4): 605-626.

11. Brown, S., Kin, L., Lys, T. (1999). Use of $\mathrm{R}^{2}$ in accounting research: Measuring changes in value relevance over the last four decades. Journal of Accounting and Economics, 28(2): 83-115.

12. Collins, D.W., Maydew, E.L., and Weiss, I.S. (1997). Changes in the value relevance of earnings and book values over the past forty years. Journal of Accounting and Economics, 24(1): 39-67.

13. Core, J.E., Guay, W.R., and Van Buskirk, A. (2003). Market valuations in the new economy: An investigation of what has changed. Journal of Accounting and Economics, 34(1-3): 43-67.

14. Dechow, P.M. (1994). Accounting earnings and cash flows as measures of firm performance: The role of accounting accruals. Journal of Accounting and Economics, 18(1): 3-42.

15. Dimitrov, V., and Jain, P. C. (2008). The value-relevance of Journal of Accounting, Auditing, and Finance, 23(2): 191-222.

16. Fama, E., and French, K. (1997). Industry costs of equity. Journal of Financial Economics, 43(2): 153-193.

17. Fama, E.F., and MacBeth, J.D. (1993). Risk, return, and equilibrium: Empirical tests. The Journal of Political Economy, 81(3): 607-636.

18. Feltham, G., and Ohlson, J. (1995). Valuation and clean surplus accounting for operating and financial activities. Contemporary Accounting Research, 11(2): 689-731.

19. Financial Accounting Standards Board (FASB). (1978), Objectives of Financial Reporting by Business Enterprises. Statement of Financial Accounting Concepts No. 1. Financial Accounting Standards Board, Norwalk, CT.

20. Francis, J., and Schipper, K. (1999). Have financial statements lost their value relevance? Journal of Accounting Research, 37(2): 319-352.

21. García Lara, J.M., García Osma, B., Penalva, F. (2011). Conditional conservatism and cost of capital. Review of Accounting Studies, 16 (2), 247-271.

22. Givoly, D., and Hayn, C. (2000). The changing time-series properties of earnings, cash flows, and accruals: Has financial reporting become more conservative? Journal of Accounting and Economics, 29(3): 287-320.

23. Givoly, D., Hayn, C.K., and Natarajan, A. (2007). The Accounting Review, 82(1): 65-106.

24. Guay, W., and Verrecchia. (2007). Conservative disclosure, University of Pennsylvania, Working Paper.

25. Jenkins, D.S., Kane, G.D., and Velury, U. (2009). Earnings conservatism and value relevance across the business cycle. Journal of Business Finance and Accounting, 36(9-10), 1041-1058.

26. Holthausen, R.W., and Watts, R.L. (2001). The relevance of the value-relevance literature for financial accounting and standard setting. Journal of Accounting and Economics, 31(1-3): 3-75.

27. Hui, K.W., Matsunaga, S., Morse, D. (2009). The impact of conservatism on management earnings. Journal of Accounting and Economics, 47(3): 192-207. 
28. Kinney, W.R., Uecker, W.C. (1982). Mitigating the consequences of anchoring in auditor judgments. The Accounting Review, 58(1): 55-69.

29. Klein, A., and Marquardt, C. A. (2006). Fundamentals of accounting losses. The Accounting Review, 81(1): 179-206.

30. Kwon, S.S., Yin, Q.J. Han, J. (2006). The effect of differential accounting conservatism on the 'overvaluation of high-tech firms relative to low-tech firms'. Review of Quantitative Finance and Accounting, 27(2): 143-173.

31. Lennox, C.S. (1999). Audit quality and auditor size: An evaluation of reputation and deep pockets hypotheses. Journal of Business Finance and Accounting, 26(7-8): 779-805.

32. Leone, A.J., Wu, J.S., and Zimmerman, J.L. (2006). Asymmetric sensitivity of CEO cash compensation to stock returns. Journal of Accounting and Economics, 42(1-2): 167-192.

33. Lev, B., and Zarowin, P. (1999). The boundaries of financial reporting and how to extend them. Journal of Accounting Research, 37(2): 353-385.

34. Lev, B., and Sougiannis, T. (1996). The capitalization, amortization, and value-relevance of R\&D. Journal of Accounting and Economics, 21(1): 107-138.

35. Ohlson, J. (1995). Earnings, book values, and dividends in equity valuation. Contemporary Accounting Research, 11(2): 661-687.

36. Ohlson, J. (2001). Earnings, book values, and dividends in equity valuation: An empirical perspective. Contemporary Accounting Research, 18(1): 107-120.

37. Ou, J., and Penman, S. (1989). Financial statement analysis and the prediction of stock returns. Journal of Accounting and Economics, 11(4): 295-330.

38. Penman, S.H., and Zhang, X-J. (2002). Accounting conservatism, the quality of earnings, and stock returns. The Accounting Review, 77(2): 237-264.

39. Qiang, A. (2007). The effects of contracting, litigation, regulation, and tax costs on conditional and unconditional conservatism: Cross sectional evidence at the firm level. The Accounting Review, 82(3): 759796.

40. Ryan, S. G., and Zarowin, P. A. (2003). Why has the contemporaneous linear returns-earnings relation declined? The Accounting Review, 78(2): 523-553.

41. Schipper, K. and Vincent, L. (2003). Earnings quality. Accounting Horizons, 17: 97-110.

42. Skinner, D. (1994). Why firms voluntarily disclose bad news. Journal of Accounting Research, 32: 38-61.

43. Watts, R.L. (2003a). Conservatism in accounting part I: explanations and implications. Accounting Horizons, 17(3): 207-221.

44. Watts, R.L. (2003b). Conservatism in accounting part II: evidence and research opportunities. Accounting Horizons, 17(4), 287-301.

45. Watts, R.L., and Zimmerman, J.L. (1990). Positive accounting theory: A ten year perspective. The Accounting Review, 65(1): 131-156. 